RUSEL Working Paper No. 38, Department of Politics,

University of Exeter, July 2000

Richard Bellamy and Dario Castiglione

\title{
The Normative Turn in European Union Studies: Legitimacy, Identity and Democracy ${ }^{1}$
}

By raising fundamental questions about the methods and ultimate goals of European integration, Maastricht forced supporters and opponents alike to confront the legitimacy both of the Union and - as has become apparent with the crisis of the Santer Commission - of the institutional architecture put in place to steer it. ${ }^{2}$ The strategic-oriented action and normative argument avoided for so long by the main political actors, are inescapable when tackling this issue. Thus, national politicians and European authorities have self-consciously, though perhaps confusedly, been obliged to start discussing the future shape of what Jacques Delors once called 'un object politique non-identifié.' Academics, for their part, have discovered that the integration process depends not simply on functional efficiency and certain given economic and national interests, ${ }^{3}$ but also on people's ideals and perceptions. Consequently, explanation and justification have proved less easily distinguishable than earlier positivistic and behaviouralist models assumed. Hence, the 'normative turn' in European studies. ${ }^{4}$

In this essay we wish to clarify certain aspects of the normative turn (section 1) and to explore some of the substantive issues that emerge from subjecting the European integration process to normative scrutiny (sections 2, 3 and 4). In the conlusion, we shall sketch the kind of normative politics we feel best suits the emerging European polity. ${ }^{5}$

\section{Normative Arguments}

Only when the intellectual history of European integration has been written, shall we know how far academic views and prejudices have shaped the perceptions of the main political actors. Part of this influence is filtered through artificial disciplinary distinctions that are as inevitable, given the complex organisation of the production and transmission of knowledge in modern societies, as they are often confusing. Though talk of a normative turn reflects a partial break-up of traditional subject boundaries within the social sciences, some clarifications are in order to avoid misunderstandings arising from different disciplinary discourses.

Within international relations - one of the fundamental discourses shaping integration theory normativism was for a long time synonymous with idealism. ${ }^{6}$ As such, it was opposed to realism, which became the dominant view as the post-First-World-War order started to collapse. A similar opposition between normativism and realism, both articulated within a positivistic idiom, was played out more or less at the same time in theories of international and constitutional law by authors such as Kelsen and Schmitt respectively. Functionalism and later, in the post-war period, neo-functionalism, added the growing interconnectedness of the international economy and the states-system to this picture. But this perspective reduced the scope for politics, as informed and strategically-oriented action, even more by subordinating it to the broader effects of spill-over, task-oriented, functional and imitative processes.

The rise of normative theory in European integration studies largely reflects the discovery that politics, in both its trategic and legitimating senses, matters. The normative turn to which we and other commentators refer, ${ }^{7}$ however, does not imply a return to idealism. It does not mean simply giving norms or grand ideals their due as political motives to counterbalance their underplaying or neglect by realism, intergovernmentalism and functionalism. The normative turn suggests these latter scenarios also have a normative dimension, since they draw on a broadly utilitarian ethic. In certain historical circumstances, 
moreover, the quest for political legitimacy requires a shift to a more intentionalist paradigm. In these cases, we need reasoned arguments and justifications for the direction we wish to take and the methods we propose employing. Whether reason and ideals, by themselves, motivate people, is a different question. The normative turn, therefore, is not solely or necessarily an attempt to idealise political and social processes. It is principally, and need only be, an evaluation of different scenarios of the integration process in the light of normative criteria. Normative acceptability of this external kind does not turn on any internal identification with the EU's ideals on the part of those involved, even if the two aspects are more linked than functionalist and realist accounts have hitherto acknowledged.

This reading of the normative turn may appear odd in view of two other developments in European studies. One is the recognition that European integration needs to be understood within a more global process of supra- and infra-national governance. The other is the conviction that the constitutionalization of the European Union and its Communities has deposed the traditional concept of state sovereignty from its central place. If anything, both developments would seem to reinforce some of the intuitions of early functionalists, while placing the emphasis less on the politics of interests and strategies, and more on the systemic character of the integration and constitutionalization processes. ${ }^{8}$

Governance discourse claims to capture the growing complexity of contemporary decision making, characterised as it is by polycentrism, fragmentation and a multiplication of institutions that cut across more hierarchical structures of power. The first message of governance - it has been argued - is to challenge constitutional and formal understandjngs of governmental systems, ${ }^{9}$ so that the complex architecture of globalized and fragmented decision making is set free from the normative codes traditionally associated with a more personalised conception of government. This thesis contains much truth. Though some theories of global governance are overstated, the general thrust of recent developments probably points in this direction. ${ }^{10}$ However, that something is occurring does not make it automatically a good thing. Even if these developments are inevitable, that merely makes them the background conditions to be taken into account by any plausible form of legitimate governance. For unless one dismisses issues of legitimacy altogether, then those who are convinced that global and transnational governance has become a fact of life (or is it a new version of the forward march of history?) still need to come up with new kinds of legitimacy appropriate to these circumstances. Hence normative arguments acquire greater relevance and centrality rather than less, since at stake is the justification of different socio-political arrangements.

Similar points arise in the welcome application of constitutional law thinking to the European Union. ${ }^{11}$ The application of legal models to the EU has proved as contested as the alleged shift from government to governance, since many jurists maintain only a state can properly possess its own law and constitutional norms. The main disagreement lies between those who still consider the Union the product of simple treaties in international law, and those who see it as having a constitutional order ex proprio vigore. ${ }^{12}$ Even more than the governance debate, this dispute turns on how the agents are conceived. Whether the Union is an international organisation or a form of polity is neither a fact of nature nor determined independently of the intentions of the agents involved. It could be maintained that socio-legal relations are as autonomous from the control of individuals and collectivities as socio-political forces and developments are. If - the argument runs - a regular pattern of socio-legal relations develops between different states and their respective populations similar to that characterising a political community, this would automatically give rise to a new political entity, regardless of peoples' perceptions. However, in spite of an important cumulative effect that may escape human control, socio-legal relations are more directly determined by peoples' choices than socio-political relations normally are. Nor does the standard version of the unintended consequences argument apply to legal, as it may to economic, relationships. Without seeking to settle the more philosophical dispute over the instrumental versus the systemic nature of legal orders, it can be argued that an important element of collective self-perception is involved in the shift from an inter-state system to a political community, and that each may involye different theoretical languages. This difference is often characterised in terms of the theory of internatlonal law and politics, which seeks to control external risks and uncertainties, and hence consists in a theory of survival, on the 
one hand; and a theory of law and politics in its proper sense, which aims at establishing human control over social life, and is therefore based on a theory of the good life, on the other. ${ }^{13}$ The crucial change when shifting from the international to the community language - whether one qualifies this in communitarian or cosmopolitan terms - lies in the sense of collective identity that is acquired in the passage. There is no avoiding subjective perceptions in the latter.

Within this context, the return of constitutional thinking to the forefront of European integration discourse is part and parcel of the normative turn. This gives a different twist to constitutional discourse, which is no longer seen in its mainly positive and doctrinal aspects, nor as the mere description a system of government; but involves the broader meaning of 'constitution' as both the construction and socio-political composition of European civit society. At this stage of the integration process, the main issue lies in what Francis Snyder has described as the passage from the existence of a European constitution in the substantive sense (the totality of norms making up the legal order of a polity) ${ }^{14}$ to a constitution in the subjective sense (implying the recognition of the subjective orientation of the people towards the substantive constitution itself). ${ }^{15}$ As Snyder says, 'dealing with the issues raised by this perspective is one of the principal tasks for EU policy-makers in the next decade. Sinutaneously it is a major challenge to EU constitutional law scholarship. ${ }^{16}$ The fundamental issues involved here are the relationship between the constitutiopal order and society as a whole; that of authorisation (the nature and forms of the constituent power); and that of legitimacy in both a social (acceptance and consent) and normative sense (underlying values; recognition of interests, opinions and identities). ${ }^{17}$

Considering the issues raised by both the governance and the constitutional perspectives, the main task currently facing Eurbe is how 'to organise relations of [legitimate] authority in a nonhierarchical and polycentric polity. ${ }^{18}$ Here we come to the final clarification of the nature of the normative turn. We have associated this turn in academic interest to the return of grand politics in Europe. ${ }^{19}$ This is similar to what Daniel Wincott in this same volume refers to as the political projects around the Europen Union. ${ }^{20}$ Naturally, such projects are suffused with the kind of normative arguments that are central to the normative turn. But the way in which formative arguments enter into the political projects is not necessarily the same as the way the academic literature looks at them. Of course, academic texts are also political acts in the sense the contextualist revolution in the history of political thought has long maintained. ${ }^{21}$ As argued in relation to the constitutionalnature of the Union, looking at it from a particular perspective is also to make a political statement. 2 However, there are three crucial differences that need to be noted. First there is a difference of style and intention. The academic literature can afford to be less prescriptive and hortatory in its formulations. This also implies that it is easier for it to take a more detached and anthropological view of the integration process by re-describing it in terms that may differ from those mployed by the participants themselves. ${ }^{23}$ Secondly, the academic approach to normative questions is less open to the contingencies of political action and tegies, which instead play an integral part in articulating a political project. In this sense, political practice is more open-ended and therefore creative in dealing with normative dilemmas (something that may give rise to unexpected goods as well as bads). ${ }^{24}$ Thirdly, and perhaps in this context the more important difference, the normative perspective is a second-order discourse, some would call it a meta-discourse, ${ }^{25}$ within the academic literature. It does not simply use value-laden arguments or try to apply them, but also enquires into the strength of conviction that normative arguments carry with them, and their internal coherence and external feasibility. This is what really distinguishes appeals to norms, as done in first-order political literature, from the exploration of the reasons underlying norms, which is what the literature on the normative turn is supposed to contribute to European studies.

\section{Legitimacy and the Three European Deficits}

As we suggested at the beginning, the new focus produced by the normative turn is on the legitimacy of ends and means. Up to Maastricht, question begging was an intrinsic part of the principal integration strategy. According to the so-called Monnet or Community method, Europe was to be made in the details through administrative means and elite bargaining. Legal rules and democratic decision making merely 
offered ex-post endorsements of an already existing reality. This method had the advantage of allowing a federal structure to be formed by stealth, while keeping nation states in control of the overall direction of the process. As a result, it pleased both federalists and intergovernmentalists, and has proved compatible with analyses from each of these perspectives. Political debate and directly consensual forms of legitimation were eschewed as either irrelevant to technical matters or inappropriate for inter-state bargaining. Moreover, discussion of the ultimate shape and scope of the EU was carefully avoided..$^{26}$ The project possessed the social legitimacy offered by good economic performance and responsiveness to demands from infra-national groups and organisatibas (or European civil society at large), and the formal legitimacy provided by the international law framework (pacta servanda sunt) within which the various Treatises ere agreed. But its political legitimacy was the indirect and weak result of the negotiations having been carried out by elected national politicians and their civil servants.

Recently, however, social and legal legitimacy have become more problematic, and the need for direct political legitimacy correspondingly greater. ${ }^{27}$ In the immediate post-war period, peace and prosperity were seen as obvious public goods that required co-ordinated European action to be achieved. ${ }^{28}$ The end of the cold war and a slowing up of fifty years of steady growth have changed that perception. What is required to secure these basic goods is now more disputed. Many analysts contend peace depends on states simply being liberal democracies rather than on their joining together into a single unit. Likewise, global markets certainly necessitate inter-state co-operation to establish free trade and regulate them, but how much beyond that is less clear. The old social democratic consensus on such matters has come increasingly under attack from the new right and the experiments with privatisation adopted in almost all the member states since the 1980s. The Common Agricultural Policy, for example, is likely to prove ever more contentious, as are the degree and character of regulations in areas such as health and safety and the environment which impose direct costs and produce only diffuse and indirect benefits. As friction over issues such as fishing rights reveal, nation states are not averse to defecting from collective arrangements whenever it seems in their short-term interest to do so and free-riding on the efforts of others. The proliferation of opt outs over matters such as the Euro testify to increasing disagreement over what economic and social policies are in the common interest. Meanwhile, expansion to the East and attempts to extend the public goods supplied by the EU are liable to heighten these tensions by raising the costs and decreasing the benefits available to existing members.

The formal legitimacy offered by law has been unable to make up for the lessening of the EU's social legitimacy. Indeed, in some respects the dramatic growth in legal integration may have exacerbated the situation. Even those scholars who believe the member states still control the overall process accept that the gradual constitutionalization of the Treaties through successive judgements of the ECJ and Intergovernmental Conferences means some form of supranational constitution is in the making, requiring a reconsideration of the methods, aims and principal agents of integration ${ }^{29}$ However, this extension of legal integratibn has often appeared to overstep not only what seems socially and economically rranted, but also the substantive values and express wishes of the populations of the member states. This conflict has been particularlyevident in the clashes between the ECJ and national constitutional courts in cases such as Grogan, where the ECJ's defence of the EC's core principles, the four market freedoms, have been opposed to an even higher law emanating from the national Demos of the member state involved. ${ }^{30}$ A similar concern lay behind the German Federal Constitutional Court's Brunner ruling ${ }^{31}$ and the uneasy ratification of the Maastricht Treaty by the British parliament and by referenda in Denmark and France. In these situations, the formal legality of the ECJ's judgements proves no substitute for its lack of substantial legitimacy. ${ }^{32}$ The Court's increasing willingness to refer to notions of rights thatstrictly speaking lie outside the domain of European law indicate the dilemma it now finds itself in ${ }^{33}$ However, since these rights can be subject to incommensurable interpretations by different national jurisdictions, this manoeyvre does not circumvent the possibility of conflict but merely moves it to a more fundamental level. ${ }^{34}$ me prominent legal commentator has even likened the potential stand off between the ECJ and national constitutional courts to the Cold War policy of Mutual Armed Destruction. ${ }^{35}$ 
As already suggested, the retreat of the Community method and its associated political strategies and forms of legitimation has produced a shift to an intentionalist paradigm that relies on more direct forms of consensual legitimacy. ${ }^{36}$ For the exhaustion of the EU's social and formal legitimacy can be remedied only through an explicit political commitment to a particular form of Union. As a result, academic attention has focused on the EU's democratic deficit with a renewed urgency. This is often seen as a question of the poor accountability of rulers to the ruled within the complex structure of the EU. Analysts note how European issues are rarely decisive in national elections, thereby undermining claims that decisions by the Council of Ministers or at Intergovernmental Conferences have the implicit approval of the various domestic electorates of the politicians involved. They also lament the weakness of the European Parliament and the general obscurity of the EC's decision-making processes particularly the shady dealings of comitology - and the resulting largely unassailable position of the Commission. Because it upholds directives that are sometimes viewed as imposed rather than democratically enacted, and employs legal reasoning that can be perceived as alien, the European Court of Justice's standing has also come to be questioned.

Whilst Europhobes suggest this anomalous situation calls for a drastic reduction of the EU's powers, most pro-Europeans advocate normalising its arrangements by making it more like a liberal democratic state. For them, the remedy lies in strengthening the Parliament's role as the main representative institution within the context of an increasingly federal European political system possessing a written European constitution and a central constitutional court. This argument begs several important questions, however, as a number of politicians and academics have increasingly come to realise. Why democratic accountability at the European level matters, and to whom, largely go unexplored in this proposal. To assert that most Europeans value democracy and the rule of law, though no doubt true, does not get us very far. One cannot assume that they either want it for the same reasons, or wish to exercise it together. There are various forms of democratic rule entailing different kinds of constitutional settlement, and a range of European constituencies and peoples who might wish to employ them for diverse and not always compatible purposes. Which democracy is appropriate and when turns to a large degree on who wishes to participate and what it is supposed to achieve.

These questions reveal three dimensions to the EU's democratic deficit, two of which are rarely addressed. First, there is the democratic deficit in the narrow sense of the relative absence of any influence by ordinary citizens over European decision-makers and the policies they enact in their name. Second, there is the federal deficit. This arises from the ambiguous relationship between the central EU institutions, such as the European Court of Justice, the European Parliament and the Commission, on the one hand, which claim a federal status within their respective domains, and national parliaments, courts and bureaucracies, on the other, which frequently dispute or seek to qualify such claims. Finally, there is the constitutional deficit. This refers to the lack of any systematic normative and popular legitimation of European political institutions due to the paucity of sustained debate about their overall shape and reach even by the political and bureaucratic élite. If the first deficit focuses on democratic accountability and representation, the second raises the issue of the distribution of sovereignty, and the third the problem of the EU's legitimacy. The three are interrelated. How one tackles the first of these deficits will largely be framed by one's thinking on the broader issues raised by the second and third. For the type and degree of democracy suitable for everyday political decisions rests to a great extent on the ways sovereignty is parcelled out and the degree to which it is regarded as legitimate for a given body to make them. These dimensions define the scope, content and sphere of democracy - who makes decisions about whom, why, when and where .

The standard Europhile view of the democratic deficit, rehearsed above, ignores the issues raised by the federal and constitutional aspects of the problem. It simply assumes a straightforwardly federal organisation of power and the popular and substantive legitimacy of a European polity. These assumptions are contentious on both normative and empirical grounds, however, and create an easy target for those Europhobes who wish to question the European project tout court. To meet such objections, it is necessary to offer an account of the constitutional and democratic structure of the Union that is as 
complex and open as the various social and political forces driving the process of integration. We shall try to do this in the next section by discussing the constitutional and federal deficits (with particular attention to issues of identity and sovereignty), whilst in the following one we shall turn to the democratic deficit more narrowly understood.

\section{Sovereignty and Identity}

Commentators appear to have reached a 'negative' agreement on the sui generis nature of the EU's constitutional structure. The novelty of the EU perplexes, attracts and repels in equal measure. The EU and the various European Communities are supranational organisations established in a piecemeal way by international treaties that have taken on a life of their own. What disconcerts observers the most is that the EU possesses so many of the features of a state without its actually being one. On the one hand, the EU controls various spheres that traditionally have been associated with states - regulating much public and private behaviour, allocating and generating revenue, and concluding international agreements on certain trade and security matters - and has many statist characteristics, such as its own bureaucratic, judicial and political systems. On the other hand, it cannot be classified as a sovereign constitutional nation state in the manner of its constituent members. The defining attributes of a congruence of territory, functional authority and national identity; a monopoly of legitimate violence within its borders; exclusive control over the movement of goods and persons within its domain; a clear locus and hierarchy of power and offices; and pre-set limits to its area of competence - all these are absent. In spite of having a Court, an Executive and a Parliament, there is no real separation of powers, and the democratic and legal checks that do exist are far weaker than those Europeans take for granted in their own polities.

A full diagnosis of what we have described in the previous section as the EU's current political legitimation crisis requires some understanding of these perplexing features. This implies two interrelated tasks that EU scholars have too often kept distinct. The first involves analysing the nature of the emerging European polity, the second exploring what type of regime or system of governance is best suited to enabling the EU deliver the democratic goods on which political legitimacy rests. Integration theorists have tended to concentrate on the polity formation aspect of the question and democratic theorists on the regime aspect. However, theories of political integration that do not address its democratic character are normatively blind and lack a sense of where they ought to be headed, whilst democratic theories that are formulated in ignorance of the political shape of the EU prove empirically empty and so unable to make the democratic ideal a reality. Rendering the EU politically legitimate entails seeing how these two dimensions might mutually influence each other, with the character of the EU polity shaping the form the democratic regime takes and being in its turn shaped by democratic decision making.

The distinction between polity and regime ${ }^{37}$ reveals two dimensions to political legitimacy. The polity dimension concerns the legitimacy of the political community as a bounded entity wishing to determine its affairs. This is largely a question of political identity, and democratic theory per se cannot resolve it, since democracy presupposes a relatively autonomous group amongst whom its decisions are binding. ${ }^{38}$ In the modern world, nation states have come to represent the natural locus of political decision making, sanctioned internally by their monopoly over the legitimate use of force and externally by a system of international law based on state sovereignty. Throughout the past two hundred years, claims topolitical autonomy and self-determination have been couched in terms of either nationhood or statehood, therefore, with the one very often meant to imply the other. As suggdested by the description of the perplexing features of the EU, recent developments towards global governance have been taken to prise open the internal connection between nation and state, as well as to undermine the logical structure of state governance. On the one hand, it is argued that nationhood no longer supplies the socio-cultural glue political integration requires to operate with the unconditional assent of the people living in a given territory. ${ }^{39}$ On the other hand, the congruence between territoriality and functional competence underlying (hierarchically ordered) state power is said to have broken down. ${ }^{40}$ These developments 
therefore point to the new European polity being postnational in character and post-state in form. It is within this new context that one needs to situate more general discussions about the end of sovereignty. The nation state, it is argued, no longer represents the fundamental political, legal and administrative focus for the mediation of diffuse social interests. It does not control important decisionmaking mechanisms; nor is it capable of expressing a common identity that can sustain a shared sense of justice and the common good. In the face of this double crisis of sovereignty, there have been growing demands for cosmopolitan and supra-national institutions and arrangements on which to base a pluralistic understanding of global democracy and justice. The constitutional organisation of the European Union, it is therefore argued, should reflect such arrangements. Although there may be some truth in such a position, the implied death-knells for the nation-state and the idea of sovereignty are perhaps premature. A brief analysis of the latter may help us to see why.

Simply put, sovereignty in a state is the capacity to control and direct its internal and external affairs without depending on other powers (superiorem non recognoseens). However, it is a matter of dispute whether sovereignty only admits of an 'absolutist' conception of politics, where power is organised in such a way that there is always an ultimate and supreme authority. A more pluralist conception of politics considers sovereignty as the relative superiority and independence of certain powers and/or political formations within particular contexts, without necessarily establishing a monistic and hierarchical system (with the sovereign at the apex), or a system of completely separate monads (of fully sovereign states).

This more pluralist conception of sovereignty finds support in an analysis of the concept that distinguishes between the internal/external meanings of sovereignty; ${ }^{41}$ and its horizontal and vertical dimensions. Historically, internal and external meanings of sovereignty have represented the two faces of the formation of the modern state as viewed from within or without. Throughout this process, external sovereignty (the power of acting autonomously with regard to both internal and external affairs) and internal sovereignty ('who' has the authority to make decisions with regard to both internal and external affairs) have normally tended to reinforce each other. But globalization, individualisation and multiculturalism seem to have changed this traditional symmetry, expressed in the unity of the nationstate, by problematizing the simple relation between space for action (external sovereignty) and capacity of action (internal sovereignty). This has important consequences not only for the nation state as the sole locus of legitimate sovereignty, but also for the idea of sovereignty in general, as the capacity of any political unit to exercise self-determination.

The distinction between the horizontal and vertical dimensions of sovereignty comes in here. Sovereignty can be apportioned both horizontally (in relation to competencies and decision-making areas) and vertically (in relation to territorial units). The separation of powers and federalism respectively provide the classic examples of each type of distribution. Within nation states these two forms of distribution have been part of a hierarchical system. Sovereign power has been divided at the centre, though usually with a mechanism for overcoming deadlock and forcing a decision, and devolved down to lesser units. But as the relations of external and internal sovereignty become more complex, this hierarchical picture breaks down. Instead, we need to reconceptualise sovereign power as being horizontally and vertically dispersed between different bodies. In our view, this offers the most promising account of the hitherto ill-defined concept of subsidiarity.

Within the EU, hierarchical, external sovereignty have been gradually acquired with little direct involvement of the peoples of Europe in whose name and over whom it is exercised. In consequence, a gap has opened up between legal and legitimate forms of political authority, internal and external sovereignty, with the EU's hierarchical claims being challenged by relatively autonomous vertical and horizontal sources of power. Moreover, these latter sources often possess greater internal sovereignty through being located in nationally or regionally controlled bodies with which people identify more. Unsurprisingly, the question of political identity and the lack of a European 'Demos' has become crucial to the issue of a future European polity. The appropriate response turns on whether the EU's aim is taken to be the creation of a European people or merely the establishment of a closer Union amongst the 
European peoples. If the former, then the removal of Europe's constitutional and federal deficits will occur through increasing the people's role within centralised European institutions. In this scenario, the EU simply becomes a supranational federal state, that can claim a union of internal and external sovereign power that can be hierarchically distributed. Yet that solution assumes a European Demos to be in place. The same holds true even if we assert, as some theorists have done, that the constitution itself is sovereign. For a general consensus on the legitimacy of liberal democratic arrangements and principles does not amount to an agreement that it is legitimate for us to be governed by any set of institutions that embodies these values and practices. They are simply too indeterminate to give precise answers to what we should do any given situation. Deciding the right balance between welfare and defence, say, or the right to privacy and freedom of information, can only occur amongst a people who conceive of themselves as sharing certain collective purposes and interests, and hence appropriately subject to common institutions. However impeccable the credentials of the EU's political regime, it will be illegitimate if the particular form of the European polity within which it operates lacks legitimacy.

If the European reality, as most commentators now acknowledge, is a more complex picture of multiple Demoi, then we shall need to create a European polity on the basis of a more pluralist conception of sovereignty. From this pluralist perspective, the present constitutional structure can be described as a mixed system. Nation states remain the dominant players, giving the EU many of the features of a confederation. ${ }^{42}$ However, they sit alongside the supra- and to some extent post-national institutions of the Commission, Parliament, the European Court of Justice and now the European Central Bank. Meanwhile, the EU has encouraged the growth of political groups of a sub and a transnational kind. For example, there are now over 3000 interest groups and a 100 regional offices based in Brussels. Many are directly involved in formulating policy via the process of comitology. Correspondingly new levels of decision making have also emerged that vary according to the policy and groups involved. However, this is not a hierarchical system. There is growing disagreement over core policies, with only 10 of the 15 being members of the EU's putative defence arm, the Western European Union, 12 signing up to the Schengen accords on free movement of peoples, and 11 joining the single currency. Even at the centre there is a complicated mix between intergovernmental decision making, as in the Council of Ministers; potentially transnational, as in the European Parliament; supranational, as in the Commission; and post-national, as with the ECJ. Moreover, all these institutions have to compete and incorporate the various levels of subnational - regional, local, workplace and community - decision making. Yet there exists no clear lines of demarcated jurisdiction or overarching authority to decide disputes between them.

\section{The Democratic Deficit (strictu sensu)}

The issue of polity legitimacy and the need to accommodate demands for group identity and selfdetermination is clearly the focus of what we have called the constitutional and federal deficits. But this is only one aspect of political legitimacy. Even with nation states, it would be wrong to assume that the legitimacy of the polity guarantees the legitimacy of its governing structure or regime. In a mixed polity, however, the legitimation offered by the regime plays an especially important role in determining the legitimacy of the polity itself. In the modern world, democracy has come to be seen as the only legitimate form of state. The resulting democratic imperative holds that the institutional organisation of government (but not necessarily social governance) must reflect the main underlying principles of democracy. Denunciations of the European democratic deficit come into their own here. There is little doubt that the structure of European governance does not fully conform to any meaningful interpretation of the many standard definitions of democracy. There is no political equality in the present system of European representation. Small countries, for instance, are over-represented in both the Council, the Parliament and the Commission. The institutions of direct representation, namely the European Parliament, have no great power; the little they have is mainly as a break upon other institutions, which are in full control of both the political agenda and legislative promotion. No clear majoritarian rule operates in European decision making; or, when it does, it involves a majority of the member states rather than their citizens. Finally, none of the main European institutions fully satisfies what are usually considered as the important 
democratic principles of popular responsiveness and accountability; nor is much of the business of government subject to the normative publicity associated with transparent decision making and freedom of information.

If the European political regime must reflect the democratic imperative to be legitimate, then there are a great many democratic deficits to be overcome. Yet why and how should the democratic imperative apply, given the new conditions in which the European polity and its component nation states now operate? The very principles of democracy may need revision to meet postnational and global conditions, much as they did in taking on their modern representative form during this century as a result of democracy's extension to the masses and its application at a national scale. Addressing the European democratic deficit is not as simple as it appears. It involves both an understanding of what democracy is and what it can actually do for the legitimation of government.

The two problems just outlined, what democracy is and how it contributes to political legitimacy, are evident in the current literature on the democratic deficit, though not always distinguished with precision. A democratic deficit has been taken to mean either a lack of democratic institutions and procedures with European institutions, or a deficit of democratic legitimation for the very existence of the EU. For some commentators, the latter issue seems to be the only relevant one. For the importance of democracy as a legitimating principle makes its application imperative across the institutional spectrum. So Pogge, ${ }^{43}$ for instance, sees compelling necessity to remedy democractic deficits in both first-order decision making, when policy issues are decided, and second-order decision making, when the constitutional rules dre set up. He suggests, however, that democratic legitimacy fails to solve the problem of how to set up second-order political decision making procedures, to which, instead experts may be able to offer some answers according to more general principles of justice.

Albert Weale, for his part has focused on both aspects of the democratic deficit. In one of his works, he considers three aspects of the democratic deficit in Europe, corresponding to the three dimensions of political authority: locus, scope and decision-rules. Political authority implies the definition of the bodies entitled to exercise it (locus); of the substantive area of decision making over which political authority can be legitimately exercised (scope); and of the kind of rules most appropriate to take authoritative decisions. ${ }^{44}$ The EU fails the democratic test at all three levels of political authority, but, as Weale himself recognises, this does not say much about the role of democracy in addressing issues of legitimacy. ${ }^{45}$ Noting that the neo-functionalist type of legitimacy, focused on the benefits of European co-operation, is now insufficient, he advocates giving the EU a 'democratic baptism' through constitutional conventions and referenda, along the lines employed to ratify the US constitution in the name of 'we the people' at the end of the eighteenth century. In his view, this form of legitimacy appeals to the principles of constitutional democracy (as formulated, for instance, in Rawls's political liberalism). Like Pogge, therefore, he sees a democratic solution to the deficit at the level of second-order decisionmaking. However, he still sees problems for removing the democratic deficit with regard to first-order decision-making due to the difficulty of applying the majoritarian principle in the supranational conditions of the EU.

Weale's caution stems from his awareness that majoritarian democracy (even when placed within constitutional constraints) fails to address the question of political identity adequately. ${ }^{46}$ Taking into account the interplay between democratic institutions and political identity clearly involves the recognition that there is a complex relationship between the two senses of the democratic deficit. A more critical line has recently heen taken on this point by Van Parjis and MaCormick, ${ }^{47}$ who have both suggested that 'deficit' san undetermined concept: we need to know whether this is a maximal deficit or an optimal deficit. The implication of this analysis is that there is no guarantee that by estaplishing maximal democracy the legitimacy deficit will be addressed, nor that addressing the latter ill necessarily imply a recourse to democratic institutions and procedures.

As Nell MacCormick ${ }^{48}$ has recently and convincingly argued, no regime is entirely democratic. The European deficit of fully democratic institutions and procedures is not so unusual. The three main branches of European governance form, in his view, a mix of bureaucratic-oligarchic elements, mainly 
embodied in the Commission (but one could also add the ECJ), with forms of direct (Parliament) and indirect (Council) democratic control. This clearly makes for a mixed constitution, but, as he says, one not wholly lacking in democratic elements or democratic spirit. ${ }^{49}$ From this perspective, reform of the European mixed regime ${ }^{50}$ with regard both to its efficacy (in sustaining integration) and an increase in direct forms of legitimation (which are required by the new intentionalist paradigm) is more a matter of prudence, in designing and adapting institutions, than of acting on democratic imperatives. ${ }^{51}$ As we have argued elsewhere, the constitution of Europe should be seen as reflexive bricolage rather than grand architecture. $^{52}$

The fact that democracy in its abstract sense may not be enough to guarantee the political legitimacy of the regime is no argument against it or the democratisation of European institutions. However, any attempt to tackle the democratic deficit needs to take seriously the new demands that globalization and multiculturalism pose to democracy in the 21 st century. A European democracy has to confront the issue of political identity by finding institutional means through which to parcel out democratic power in ways that are consistent with a pluralist understanding of sovereignty. ${ }^{53}$ This is a particularly complex task, because regime legitimacy meshes with the legitimacy of the polity at this point. As we saw, the mixing and overlapping of sovereignties (multiple Demoi and multi-level governance) make Europe a mixed polity. Yet it is also a mixed regime (or commonwealth), in that there is a mixing of different elements of rule (in the classical sense of the three forms of government). As things stand, these cannot be considered transient features of the European Union. For its political legitimacy depends on the mixture of elements making up the EU being given democratic recognition and expression through a careful and sensitive allocation of powers and the design of inclusive institutions. A mixed polity requires a mixed regime.

By posing the democracy question in this way, we suggest that democracy should be seen as performing different functions in the formation, government and legitimation of a complex and supranational polity such as the EU. We also suggest that a more reflective way of considering the nature and role of democracy in such a polity is needed. This may also imply a different conception of what kind of political principles are needed in a modern complex society.

\section{Conclusion: A Political Constitutionalism}

The normative turn in the study of Europe is not simply a matter of applying political norms fashioned within the context of the nation state and applying them to the EU. Rather, it leads to a refashioning of those norms. From this perspective, the gravest deficit confronting the EU lies in the imagination. Friends and foes of the EU tend to measure it by the criteria of constitutional liberal democracy. A form of government that developed alongside the nation state, it assumes a substantive consensus on the constitutional principles framing a majoritarian or consensual form democracy, and a sense of collective identity and common purposes amongst those to whom both the constitution and the democratic decisionmaking procedures apply. The more contested principles, purposes and procedures become, the less satisfactory this set up will be. As we have seen, this situation prevails in the EU. Within a complex polity possessing multi-Demoi, we need a more political constitutionalism that fosters fair negotiation and mutual accommodation amongst its members.

This approach can be better accommodated within a pre-liberal, neo-Republican conception of constitutionalism, which identifies the constitution with the social composition and the form of government of the polity, may offer better insights for addressing those problems. Much as we associate a person's physical health with his or her bodily constitution and regard a healthy individual as someone with a balanced diet and regimen, so a healthy body politic was attributed to a political system capable of bringing its various constituent groups into some sort of equilibrium with each other. The overall aim was to disperse power so as to encourage a process of controlled political conflict and debate that ensured the various groups and social classes both checked and ultimately co-operated with each other, moving them thereby to construct and pursue the public good rather than narrow sectional interests. 
The politicised account of justice and social cohesion emerging from political constitutionalism suits a concern with domination and the fact of social and cultural pluralism. A modus vivendi built solely around a fair balance of power will not of itself produce mutual accommodation, however. It may lead to stalemate and remains compatible with majority tyranny if a given group is sufficiently large legitimately to arrogate the lions share of power to itself. The search for accommodation suggests that the quality of decision making must be different. Negotiation and mutual accommodation between differences involve a shift from a politics of interests to one based on reasons and arguments. Whilst dispersing power aids the development of such attitudes, something more positive is needed actively to encourage their adoption. None of this suggests agreement in a more substantive sense. Indeed at times it may be possible to do no more than agree to disagree, and accept the authority of the democratic procedure itself. In these cases the majority principle acts as a means for resolving conflict in an authoritative manner when a compromise on substance cannot be achieved. Authority here rests on neither claims to superior reason nor coercion but the simple acceptance of the procedure as authoritative (in the sense of being 'in' authority) for the disputing parties. Here the authority of law rests on the legitimacy of the political system which generates it. Parties acknowledge that in some cases there may not be any 'correct' or 'most just' way of resolving a clash between incommensurable plural values, but that the ways of ending the dispute are acceptable. The procedural fairness of the process of justice can be more important than the preferability or consensus about the outcome.

A more political constitutionalism does not turn on the existence of a homogeneous community, therefore, as certain communitarian theorists maintain. The political system can operate as a public good for a plurality of social groups, without assuming they share other values (indeed, perhaps for the very reason that they do not). Secession or conscientious objection may still have to be options for groups or individuals whose values and convictions prove totally incompatible with those of the majority. Their reasons could not be, however, claims to superiority - that their values and interests are worth more than those of others. Rather, the case must be that such drastic measures are necessary to ensure equal worth and that otherwise their cultures and concerns might be totally eroded. Even in these cases alternative solutions, such as greater autonomy or special rights, might be available to keep them within the polity.

It is through the development of the mechanisms of identification, participation and representation offered by political constitutionalism that collective and democratic self-determination (the capacity, that is, of embodying popular sovereignty at large) in global and multicultural societies becomes feasible yet again. The institutions of a political constitution have to be adapted to particular circumstances. An ideal political system cannot be devised a priori because the range of dispositions, traditions and social composition of a polity are highly variable factors. Existing systems, however, can be evaluated for their capacity to realise the goals of a political constitutionalism. The EU still awaits its Madison, the last proponent of this approach capable of combining normative and practical considerations in equal measure. However, a Publius needs an audience and a context that only normative debate about the EU is likely to create. 


\section{Notes}

${ }^{1}$ Research for this paper was supported by an ESRC Research Grant on 'Sovereignty and Citizenship in a Mixed Polity' (R000222446). For helpful comments and stimulating and highly enjoyable discussions, we thank the participants to the ESRC seminar series on 'Legal Theory and the European Union'.

${ }^{2}$ Cf. J. H. H. Weiler, The Constitution of Europe. "Do the new clothes have an emperor" and other essays on European integration (1999 Cambridge University Press), Ch 1.

${ }^{3} \mathrm{Cf}$. Mitrany's idea of 'the relation of things' as the core of functionalism: D. Mitrany, The Functional Theory of Politics (1975 Martin Robertson), p. 37.

${ }^{4}$ The list of works taking such a turn is growing rapidly. They are now too many to be listed without risking to leave too many of them out.

${ }^{5}$ We have developed similar arguments in R. Bellamy and D. Castiglione, 'Democracy, Sovereignty and the constitution of the European Union: The Republican Alternative to Liberalism', in The European Union and its Order, (eds.) Zenon Bankowski and Andrew Scott (Blackwell, 2000).

${ }^{6}$ Cf. P. Paul Taylor's 'Introduction' to Mytrany, The Functional Theory, p. xii

${ }^{7}$ Cf. amongst others, contributions to The European Union and its Order by Bankowski \& Christodoulidis, Everson, Walker, and Wincott.

${ }^{8}$ Cf. some of the contributions in K. A. Armstrong and J. Shaw, 'Integrating Law', (1998) Special Issue of Journal of Common Market Studies, 36, 2.

${ }^{9}$ G. Stoker, 'Governance as Theory: Five propositions', (1998) International Social Science Journal, 155, p. 19

${ }^{10}$ For a discussion of the sociopolitical aspects of cosmopolitan globalist discourse, see R. Bellamy and D.

Castiglione, 'Between cosmopolis and community: Three models of rights and democracy within the European

Union', in Archibugi et al., Re-imagining Political Community (1998 Polity Press), pp. 152-78, at 154-57.

${ }^{11}$ For a fuller discussion, cf. F. Snyder, General Course on Constitutional Law of the European Union, Collected Courses of the Academy of European Law, (1998), VI, I, pp. 41-155.

${ }^{12}$ Snyder, General Course, pp. 51-52.

${ }^{13}$ Cf. A. Linklater, Men and Citizens in the Theory of International Relations (1982 Macmillan), p. 4.

${ }^{14}$ These need not to be seen in a purely legalistic and formalistic sense. Snyder also refers to the material sense (senso materiale) of the constitution. This is a concept particularly developed within the Italian constitutional tradition capturing the fact that a constitution results from norms and practices not all of which have a formal constitutional status, General Course, p. 53.

${ }^{15}$ Snyder, General Course, p. 55

${ }^{16}$ Snyder, General Course, ibid.

${ }^{17}$ For the various meanings of legitimacy, cf. D. Beetham and C. Lord, Legitimacy and the EU (1998Longman), passim.

${ }_{18}^{\frac{p}{18} \text { Snyder, }}$ General Course, p. 55

19 'Grand' is here meant with reference to the scope of the analysis, not necessarily to the underlying ambitions for the reshaping of European society. So, those visions that support the status quo of an economic Europe, with strongly entrenched national sovereignties can be defined 'grand,' even though they purport to resist any change in the current structure of the EU. Such a view of Europe has been classified as that of a special-purpose association (Zweckverband): cf. G. Winter, 'Introduction' to Reforming the sources and categories of EC legal acts, Report for the General Secretariat of the European Consortium (March 1995), pp. 7-8; Snyder, General Course, p. 6; and R. Bellamy and D. Castiglione, 'Building the Union: The Nature of Sovereignty in the Political Architecture of Europe' (1997), 16, Law and Philosophy, pp. 421-445.

${ }^{20}$ Damiel Wincott in his contribution to The European Union and its Order laments the paucity of the academic literature on the political projects themselves. We agree with him that this is yet another perspective from which to study the European integration process, and that more work should be devoted to it; but, as we make clear below, this is different from the new normative literature to which we refer.

${ }^{21}$ To name but one text, cf. Q. Skinner, Meaning and Context, J. Tully (ed.) (1988 Polity Press).

${ }^{22}$ Cf. also Snyder, General Course, p. 52.

${ }^{23}$ For a distinction between an internal and an external perspective on the constitutional principles in Europe, cf. Snyder, General Course, pp. 75-78.

${ }^{24}$ An example of the open-endedness of political projects can be seen in the present (at the moment in which we write) crisis of the Santer Commission. The events leading to it are open both to eurosceptic and europhile 
intepretations. The former would emphasise the dangers of corruption in moving to a more integrated Europe; while the latter would lie the blame at the door of the intergovernmental structure, which is unaccountable to the representatives of the European people. Arguments can be presented in support of both views; but the effect that such arguments will have on the crisis itself will depend on which of the political projects currently in formation will carry the day.

${ }^{25}$ Cf. D.N. Chryssochoou, 'Metatheory and the Study of the European Union: Capturing the Normative Turn' (1999 Mimeo, by kind concession of the Author).

${ }^{26}$ On the process of integration so far and on its ethics, cf. R. Bellamy and A. Warleigh 'From an ethics of integration to an ethics of participation: Citizenship and the future of the European Union', (1998) 27, Millennium: Journal of International Studies, pp. 447-70.

${ }^{27}$ Cf. Beetham and Lord, Legitmacy; and P. C. Schmitter, 'If the nation state were to wither away in Europe, what might replace it?', in S. Gustavsson and L. Lewin (eds), The future of the nation-state: Essays on cultural pluralism and political integration, (1996 Nerenius and Santérus), and 'Is it really possible to democratize the Euro-polity?', in A. Føllesdal and P. Koslowski (eds), Democracy and the European Union, (1998 Springer), pp. 13-36.

${ }^{28}$ Cf. Weiler, The Constitution of Europe, 1999, Ch. 7.

${ }^{29}$ Cf. A. Moravcsik and K. Nicolaïdis, 'Keynote Article: Federal Ideas and Constitutional Realities in the Treaty of Amsterdam', (1998) 36, Journal of Common Market Studies, Annual Review, pp. 13-38 .

${ }^{30}$ Cf. J. Coppel and N. O’Neill, 'The European Court of Justice: taking rights seriously?', (1992) 29, Common Market Law Review, pp. 669-92; and B. De Witte, 'Droit communitarie et valeurs constitutionelles nationales', (1991) 14, Droits, pp. 87-96.

${ }^{31}$ Cf. D. Grimm, 'Does Europe need a Constitution?', (1995) 1, European Law Journal, pp. $282-302$.

${ }^{32}$ Cf. N. McCormick, 'The Maastricht-Urteil: Sovereignty Now', (1995) 1, European Law Journal, pp. 255-62, and MacCormick, N. 'Liberalism, Nationalism and the Post-sovereign state', in R. Bellamy and D. Castiglione,

Constitutionalism in Transformation (1996 Blackwell), pp. 141-56; and P. Eleftheriadis, 'Begging the Constitutional Question', (1998) 36, Journal of Common Market Studies, pp. 255-72.

${ }^{33}$ Cf. J. Shaw, Law of the European Union (1996, 2nd edition: Macmillan).

${ }^{34}$ Cf. R. Bellamy, 'The Constitution of Europe: Rights or Democracy?', in R. Bellamy, V. Bufacchi, D. Castiglione, Democracy and Constitutional Culture in the Union of Europe (1995 Lothian Foundation Press)

${ }^{35}$ Cf. J. H. H. Weiler, 'European Neo-Constitutionalism: In Search of Foundations for the European Constitutional Order'. In Bellamy and Castiglione (eds), Constitutionalism in Transformation, pp. 105-21.

${ }^{36}$ Cf. W. Streeck, 'Neo-Voluntarism: A new European social policy regime?', in Marks, et al., Governance in the European Union (1996 Sage), pp. 64-94; Offe, 'The democratic welfare state: A European regime under the strain of European integration' (1998 Mimeo, by kind concession of the Author).

${ }^{37}$ Cf. P. C. Schmitter How to Democratize the Emerging Euro-polity: Citizenship, Representation, Decision-making, (1996 Mimeo, by kind concession of the Author).

${ }^{38}$ Cf. R. Dahl, Democracy and its Critics, (1989 Yale University Press); A. Weale, 'Democratic Legitimacy and the Constitution of Europe', in Bellamy et al. (eds.), Democracy and Constitutional Culture, pp. 81-94; 'Majority rule, political identity and European union', in P. B. Lehning and A. Weale (eds), Citizenship, democracy and justice in the new Europe (1997 Routledge), pp. 125-41; 'Between representation and constitutionalism in the European Union', in A. Weale and M. Nentwich (eds), Political Theory and the European Union. Legitimacy, constitutional choice and citizenship, (1998 Routledge), pp. 49-62.

${ }^{39}$ Cf. D. Curtin, Postnational Democracy. The European Union in search of a political philosophy (1997 Kluwer Law International); J. Habermas, Habermas, J. Between Facts and Norms (1996 Polity Press).

${ }^{40}$ Cf. Schmitter, 'If The Nation State' and How to Democratize.

${ }^{41}$ The distinction here made between internal/external is the same of the one made by Deirdre Curtin in her Postnational democracy, pp. 11-14. As argued below, this does not reproduce the simple distinction between internal and external affairs, which is instead the kind of distinction adopted by Neil Walker in his contribution to this collection. Both uses are legitimate, but their analytical import are clearly different.

${ }^{42}$ M. Forsyth, ) Union of States - The Theory and Practice of Confederation, (1982 Leicester University Press); A. Warleigh, 'Better the devil you know? Synthetic and confederal understandings of European Unification' (1998) 21, West European Politics, pp. 1-18; D.N. Chryssochoou, 'Democracy and symbiosis in the European Union: Towards a confederal consociation?' (1994) 17, West European Politics, pp. 95-128.

${ }^{43}$ T. W. Pogge, 'How to Create Supra-national Institutions Democratically. Some Reflections on the European Union "Democratic Deficit", in Føllesdal and Koslowski (eds) Democracy and the European Union, pp. 160-85. 
${ }^{44}$ Weale, 'Majority Rule', pp. 128-31.

${ }^{45}$ A. Weale 'Single Market, European Integration and Political Legitimacy'. Paper presented at the 'Evolution of Rules for a Single European Market', ESRC Conference, University of Exeter, 8-11 September 1994;and 'Democratic Legitimacy'.

${ }^{46}$ Weale, 'Majority Rule' and 'Between representation', passim.

${ }^{47}$ P. Van Parijs, 'Should the European Union become more democratic?', in Føllesdal and Koslowski (eds), Democracy and the European Union, pp. 287-301; and N. MacCormick, 'Democracy, Subsidiarity, and Citizenship in the "European Commonwealth"' (1997) 16, Law and Philosophy, pp. 331-56.

${ }^{48}$ MacCormick, 'Democracy, Subsidiarity', at pp. 342-47.

${ }^{49}$ MacCormick, 'Democracy, Subsidiarity', at p. 344.

${ }^{50}$ Neil MacCormick calls it a mixed commonwealth. We also used mixed commonwealth in Bellamy and Castiglione, 'Building the Union', following a suggestion from MacCormick himself; but, in fact, we there meant what we now call mixed polity as opposed to mixed regime.

${ }^{51}$ Also cf. Schmitter, $\underline{\text { How to Democratize; }}$ and P. Craig, 'Democracy and Rule-making Within the EC: An Empirical and Normative Assessment', (1997) 3, European Law Journal, pp. 105-30, passim.

${ }^{52}$ See Bellamy and Castiglione, 'Building the Union ' and 'The Normative Challenge of a European Polity: Cosmopolitan and Communitarian Models Compared, Criticised and Combined', in Føllesdal and Koslowski (eds), Democracy and the European Union, pp. 254-84. Cf. also MacCormick, 'Democracy, Subsidiarity', pp. 354-56; and Curtin, Postanational Democracy, pp. 61-62.

${ }^{53}$ On this, see Cf. MacCormick's discussion of subsidiarity in 'Democracy, Subsidiarity', pp. 350-54 